\title{
The Life of a Jewish Pharmacist in Hungary
}

\author{
Attila Szabó $^{1,2}$, Miklós Vecsernyés ${ }^{1}$ and Ildikó Bácskay ${ }^{1}$ \\ 1. Department of Pharmaceutical Technology, Faculty of Pharmacy, University of Debrecen, Debrecen 4032, Hungary \\ 2. Bethlen Pharmacy, Debrecen 4026, Hungary
}

\begin{abstract}
The aim of this study is to draw a picture of a family of a Jewish pharmacist in Hungary from the beginning of the 20th century by the help of old discovered documents. It is not easy to reconstruct the life of anybody who could be a pharmacist or an owner of a pharmacist or his family life which mainly took place between the two world wars and in the following Rakosi area. We came across a pile of badly fowed pieces of paper and after analyzing them it can be stated that the examined person became the owner of a pharmacy in Szeged after he had graduated and had done his pharmaceutical practice in Budapest. Then he ran the pharmacy on his own where mainly Jewish employees were employed. However, due to the anti-Jewish laws first he had to dismisse some of his employees, later he was forced to sell his pharmacy. Surviving the war, according to the new laws he had the opportunity to claim his property again at court. Relying on the judgement it was revealed that the original pharmacist and the permanent licensed one became partners at a 50 and 50 per cent. But some time later according to Act XXV of Law 1950 all of the pharmacies in Hungary were brought under government management. Thenthe same happened to every family-owned property and they could keep only the house where they lived. Jenő Gerle died at the age of 82 in Szeged. Both his daughters managed to survive the World War II but became widows, could enjoy the hospitality of the Hungarian Socialist Peoples'Rebublic and died childless.
\end{abstract}

Key words: History of pharmacy, anti-Jewish laws, World War II., nationalization in Hungary, Rakosi era.

\section{Introduction}

In the so-called peacetime period of the Austro-Hungarian Empire after the conciliation the whole country was in the fever of construction and industrialization. The rural peasantry could sell the crops provided by agriculture and consequently there was a real economic development. But in 1914, the Great War broke out, which became global and dragged on. The battles came to the end in the autumn of 1918 with the defeat of the Central Powers. Tortured and exhausted soldiers returning home from the battlefields and the indigent population in the country, not even realised that the war against foreign countries had been over. [1, 2]. Because, not long ago, from the neighboring Tsarist Russia-where the tsar's family was murdered in the meantime and the country was under the control of the Bolsheviks - communistic-minded comrades arrived in Hungary.

Corresponding author: Ildikó Bácskay, Ph.D., assistant professor, research fields: pharmaceutical technology and propedeutics. E-mail: bacskay.ildiko@ pharm.unideb.hu.
They first founded the Republic led by Count Michael Karolyi, then between March 21 and August 1, 1919 there was a Soviet Republic existence [3, 4]. Their power in our country was boken by the soldiers of permanently occupying newly organized states-called Little Entente and their supporting French soldiers. Furthermore, the international diplomacy did not even want to negotiate with the delegates of the Commune [4, 5]. The resigned Communistic leadership was replaced by Vice Admiral Miklós Horthy as a governor. For Hungary, the tragedy caused by the war was not enough but the losses associated with the loss of huge living area and population were created. Not to mention the reparation costs. After the Trianon peace treaty, Hungary became a kingdom, independent from the Austrian crowns. The country's reconstruction started with Spanish flu, which required much more human sacrifice than the war itself. First there was lack of crops and famine, and then the storage and sale of the seemingly unmarketable crops abundance caused problems had to 
be dealt with.

(For those areas where wheat from Hungary was taken before the war wheat from the United States was shipped after the war.) When we managed to get back to market with Hungarian crops, Italy became our first customer where Mussolini's fascist party took over the political power in 1922. Later, Germany became a major trading partner to our country. The great Allied Powers did not really want to trade with us. Since more than $70 \%$ of our trading was between these two fascist countries, so the country was dependent from them both economically and politically. In the whole world anti-Semitism was in the air, but mainly due to the German leadership in Germany where camps were established in several places in order to torture and exterminate enemy people [6, 7]. From 1939 till the end of 1944 even in our country laws affecting the Jewish people's life appeared [8]. From the end of World War II till 1991, Soviet troops remained in our country. In autumn 1944 the Provisional Government was set up, which gave back the belongigns and properties of the survived Jews, and promulgated the supporting act—which meant having to prove that the person was not a member of the Nazi party, and not persecuted the Jews - this law was in till the end of 1948 [9].In 1949, the Hungarian Communists came to power again,with the leadership of Matyas Rakosi. and then in 1950 pharmacies were taken into state-owned [10].

The aim of this study is to give an overview of struggles, often tragic life of a Jewish pharmacists called Jenö Gerle. The life of Jenő Gerle based on the so-far discovered data has to be devided into two, as we need to discuss his life as a pharmacist and as a private man in the given historical period. The smaller part of the documents are about the personal life of a family that has survived very fragmentary, but seemed to be worth doing further research work because in these remained framents there is a man who survived the bloody horrors of the twentieth century as a Hungarian, as a Jew and as a pharmacist as well.
Thanks to our research work, from the Jewish archives in Szeged new fragments were found in connection with the family. Unfortunately, giving a precise and full biographical description of each family member, it is no longer possible as the research shows, there is no surviving member of the family now. This is the reason that the picture can be drawn here, could be stained and incomplete, perhaps forever.

\section{Materials and Methods}

Two files of material were found at an antiques dealer in Szeged, and when it was read over shreds of life of a pharmacist and one of his children's from Szeged emerged. After the purchase and rearrangement of the found papers, it was revealed that most of the pieces of paper involved accounts of everyday life, letters relating to real estate, tenants' names and their wages listing curved annual tax returns. Furthermore, the discovered materials tell the story of a pharmacy called "Kígyó" ("Snake" in English) which still exists.

\section{Results}

\subsection{Biography of the Family Gerle, Private Life}

The main character of the story is Jenő Gerle, who lived his life in the most devastating period of history of mankind-World War I. and II, the Soviet Republic and the Republic of Hungary, the Horthy era, Rakosi era and the revolution of 1956 . We can say briefly, he was the owner of the pharmacy called "Kígyó" in Szeged for 43 years, first between 1902 and 1941 and then between 1946 and 1950. His wealthy, middle-class family raised two daughters. Jenő Gerle, was born on 24 May 1876 in Ónod (Borsod County, Hungary), originally named Jenő Glänzer. As he was born before 1895 , that is why in the state registration his name can not be found-as in Hungary, the registration of births was introduced to public office from 1st October 1895 [11]. As a result of the domestic situations in World War II, archives paper materials of the synagogue were mostly destroyed, including documents related to Jenő Gerle. In 1898, his family 
name was applied to change to sound more like Hungarian, which permission No. 126266/1898was given by the Home Office. Earlier in Act of July 1787 Joseph II ordered that the Jewish population beside their christain names had to use their surnames which had to be German. In the trends of integration (comes from Latin in-tangere, means untouched [12] of the 19th century we can find adoptations of Hungarian names. While about the $30 \%$ of the German and Slav ethnic groups applied for the adoptations of Hungarian names, the $60 \%$ of the Jewish population did it [13]. His father, Dr. Mór Glanzer, worked as a doctor in the city of Szeged, that is why the family moved from Ónod to Szeged. All we can know about his mother called Kiss Janka is that she was from a wealthy bourgeois family and as it was usual at that time, the children's education and the household were her main tasks. We have no data about if she had a brother or a sister or what happened to her parents. However what we can suppose from the Jewish tax payments is that the Glanzer was a wealthy, religious Jewish family. We do not know exactly when the family moved from Ónod to Szeged, so there is no data about Jenö's elementary and high school education. However, it is sure that he did his university studies in Budapest where he graduated in 1899. After having done his pharmaceutical practice, he passed his approbation exam which was needed to be able and allowed to run a pharmacy [14]. In 1901 the pharmacy called "Kígyó" in Szeged was on sale, he took the opportunity and in the autumn of that year he bought it from István Érdy and moved to Szeged. Then he got married on 6th July, 1902. He married to the daughter of a wealthy couple called Adolf Weiss and Justina whose name was Alice born in Hódmezővásárhely, 1st January, 1881. One of the very, very few remained photos of the family, shows the daughter and the mother (Fig. 1). From their marriage three daughters were born. Unfortunately, they lost their daughter called Violet, very early, (Fig. 2) on 20th April, 1907.

Their next daughter, Magdalena (Aunt Chubby),

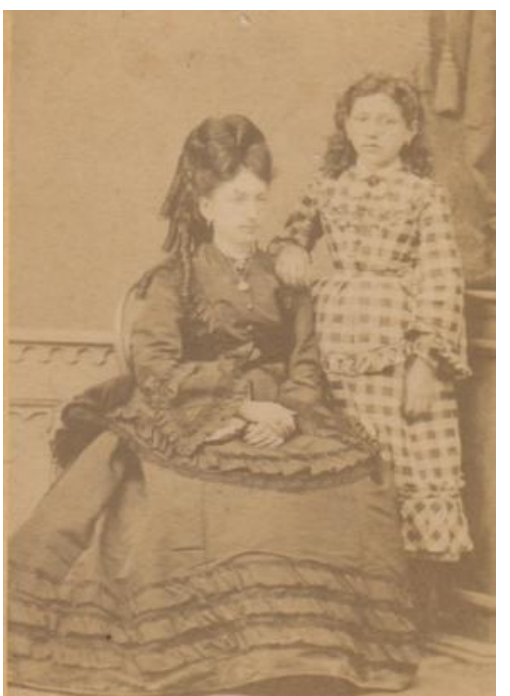

Fig. 1 Weiss Jusztina and her daughter, Adél (Alice).

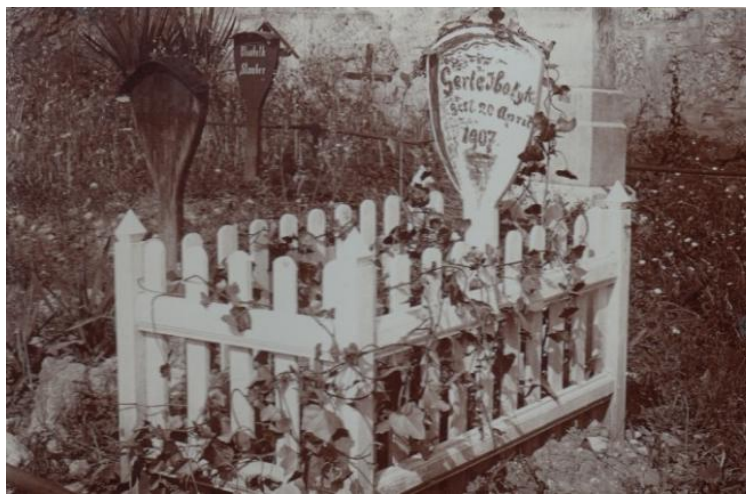

Fig. 2 Ibolya Gerle (Violet)'s grave in the Jewish cemetery, Szeged

who was born on 1st February, 1907 in Szeged. She did her elementary and high school education in Szeged, We do not know if she would have been in higher education, but it is sure that she married to the rich owner of Big Beef Slaughterhouse and Meat Factory of Szeged, called Oscar Smith. The date of their marriage is missing. After the outbreak of the war the state rented the fectora for military purpose. Later Oszkar was taken away for military service and soon died a hero's death, as it turned out from the applications for benefits to war widows. Magda lived as a widowin the rest of her life. They did not have a child. She passed away at the age of seventy-five, on 14th February 1982

There is the most remained information about their third daughter called Theodora Agnes (Dodo). Teodora 
Agnes Gerle, was born on 28th November 1916, in Szeged. She did a successful graduation exam on 25th June, 1936 in Szeged Hungarian Royal Saint Elisabeth Grammar School for girls. The Dean of Faculty of Mathematics and Science of the Royal Hungarian Emperor Franz Joseph University refused Teodora Agnes' application for the pharmacist training in a letter dated 9th September, 1939, referring to the fact that the students" number was "relatively filled". Perhaps, her parents suggested that she should work in their pharmacy for two years, but she worked there as a trainee. Then she learned to be a beautician. She got married but we could not find the exact date of it. Her husband was Dr László István Kemény who was a lawer in Szeged. Unfortunately he became a victim of the World War II. Although he died a heroic death on 12th November 1942, the family was not informed for so long that his death notice appeared in the newspaper called "Délmagyarország" on 20th February 1943. After the war she had several jobs but finally she retired from the Management of the Open-air Theatre of Szeged. During that time she failed to find happiness in marrigies. By the time she retired, she had remained alone with her illnesses and unsuccessful private and professional life. Finally on 24th August, 1985, she passed away [15].

From the wedding dower of his wife they managed to buy a portion of property of block of freehold flats at 1 Kígyó Street, Szeged. It is the house where the family lived, but they let out most of the rooms which provided nice income especially between 1940-1944.

Due to the anti-Jewish laws Jenö gerle was forced to sell the family-owned pharmacy. The new owner of the pharmacy became István Takáts. While Gerle invested the money into a property in Budapest.

It can be said that till May 1944, despite the constraints of the Jewish laws in Hungary, they could have a relatively normal family life. The men liable for military service were called for forced labor more frequently and for a longer period. In 1944 in Szeged the ghetto was set up and tortures began in the
Gestapo-run detention facilities, and also deportations were ordered. Jeno Gerle lived through the bloodiest period of the war in one of the Hungarian SS jails. They belonged to the few Jewish families in which all of the members could survive (Fig. 3).

After the war the Temporary National Government was set up in Debrecen, after the fights it moved to Budapest. Among the acts by this government we have to mention two [16]. One of them was about the Jewish properties (mentioned later), while the other one was about confirmation of state servants. Every employee had to go over the procedure of confirmation which meant that the 8- member- committee examined whether the behaviour of the examined person hurt the interests of Hungary or not. According to the Act 146 of Law 1945 the procedure of confirmation was legally binding for every pharmacist (Fig. 4).

First, Jenö Gerle's wife Alice died in 1951, so his task was to deal with the family's estate business in the future. Then, at the age of 82, in 1958, the elderly pharmacist died (Fig. 5). Later, the family owned properties were taken away by the state, they were only allowed to stay at the apartment in which they lived.

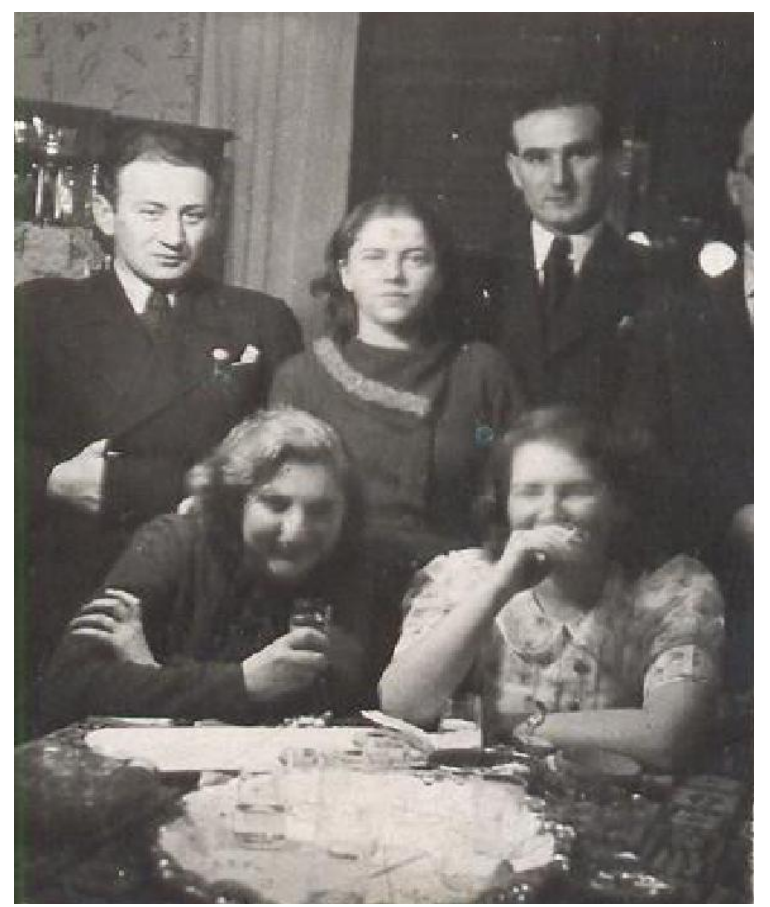

Fig. 3 The Gerle family. 


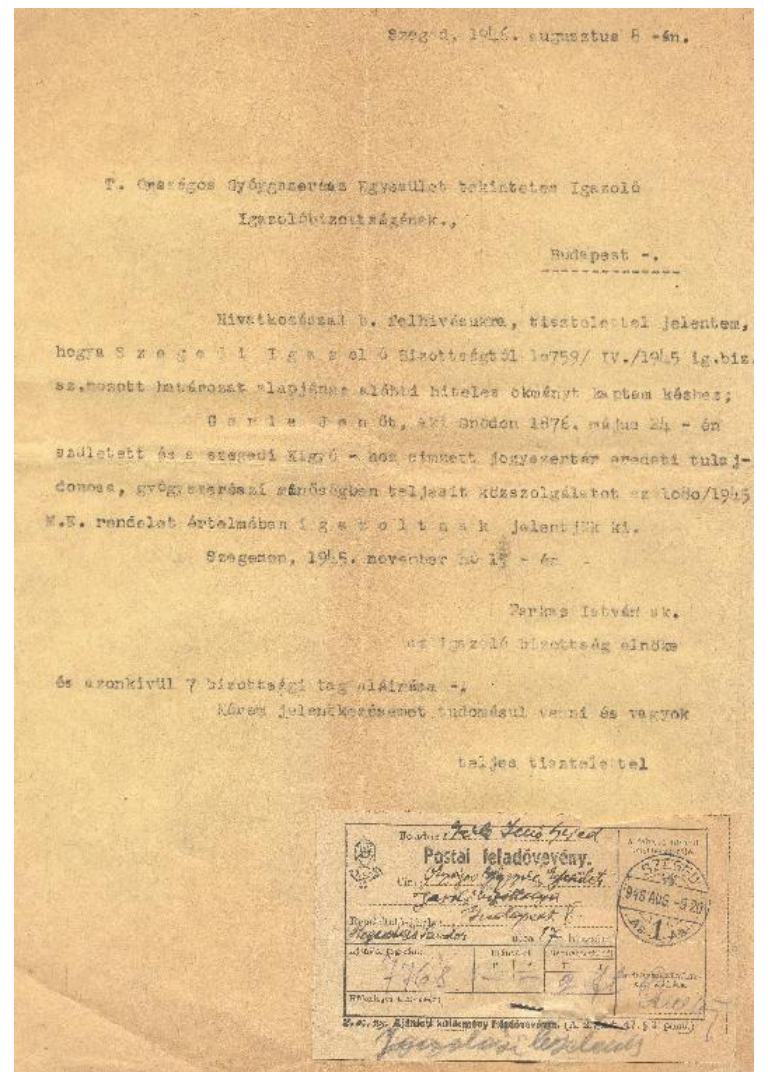

Fig. 4 Jenő Gerle's confirmation by the Certifying Commission in Szeged.

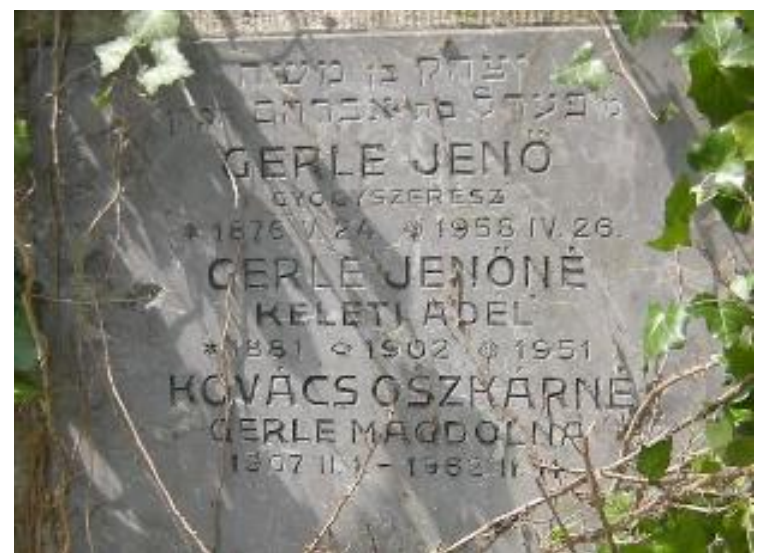

Fig. 5 Jenő Gerle's, wife Adél Keleti's and their daughter, Magdolna (Magdalena)'s common tomb in the Jewish cemetery, Szeged.

\subsection{His Life as a Pharmacist}

Nothing can be found about his pre-university studies which was pharmacists' compulsory practice. It is known that he studied and graduated in pharmacy at Pázmány Péter University, Budapest on 23rd June, 1899. His degree's registered number was 53664. His name also was changed during the university years. Graduated as a graduated pharmacist with his new name, he spent his practice years in Budapest. After he had been a prarmacist for three years, he travelled to Szeged, where he bought the pharmacy, founded in 1874, called "Snake" from Istvan Érdy. Referring to the Atricle 131 of Act XIV of Law 1876 István Érdy and Jenő Gerle requested the Home Office to give the permission to transfer pharmacy's license. They managed to get it under the announcement number 141 820/901 (Fig. 6). The Mayor's Office of Szeged, Dr. Farago, the town's chief medical officer and the chief police officer called Rainer also received a notice about this permission. So from the 1st January, 1902, Jenö Gerle as an owner led the pharmacy. At that time Szeged had a population of 85,569 inhabitants, and the city had nine pharmacies (Table 1). The bought pharmacy was moved to the corner of Kazuál square and Kárász street where it is situated even today (Fig. 6).

Due to the good turnover of the pharmacy and his wife's wealthy bourgeois Jewish family and her dowry he managed to buy the 14/16 parts of the building built in 1913. His wife was registered as an owner.

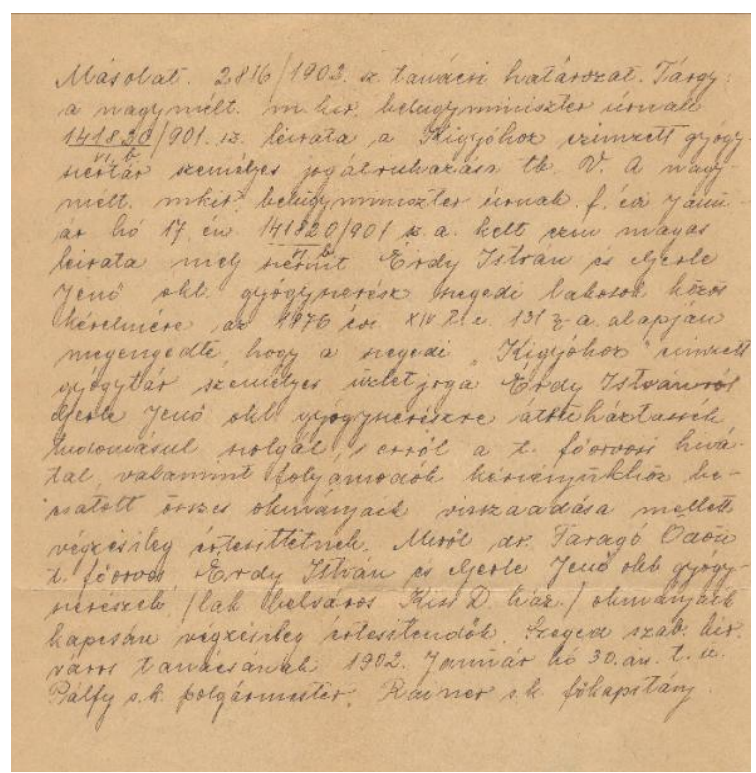

Fig. 6 Council's Decision on the "Kígyó (Snake)" pharmacy transfer. 
Table 1 Pharmacies of Szeged in 1900, according to the Yearbook of Pharmacists, pocket calendar.

\begin{tabular}{llll}
\hline Year of foundation & Name of Pharmacy & Name of Owner & Name of Tenant \\
\hline 1713 & Megváltó & Bokor A. és Vajda & - \\
1812 & Isteni gondviselés & Barcsay Károly & Szobonya K. \\
1834 & Szentháromság & Leinzinger Gyula & - \\
1850 & Segítỏ Mária & Gyuricza Lipót & - \\
$* 1856$ & Kálvária & Götz Jánosné & Dragon Gyula \\
1865 & Szent Rókus & Meák Gyné & Esztegár Béla \\
1869 & Szent György & Frankl Antal & - \\
1870 & Szent István & Bencsik Lajos & - \\
1874 & Kígyó & Érdy István & - \\
\hline
\end{tabular}

In books published later 1888 was given as the year of foundation.

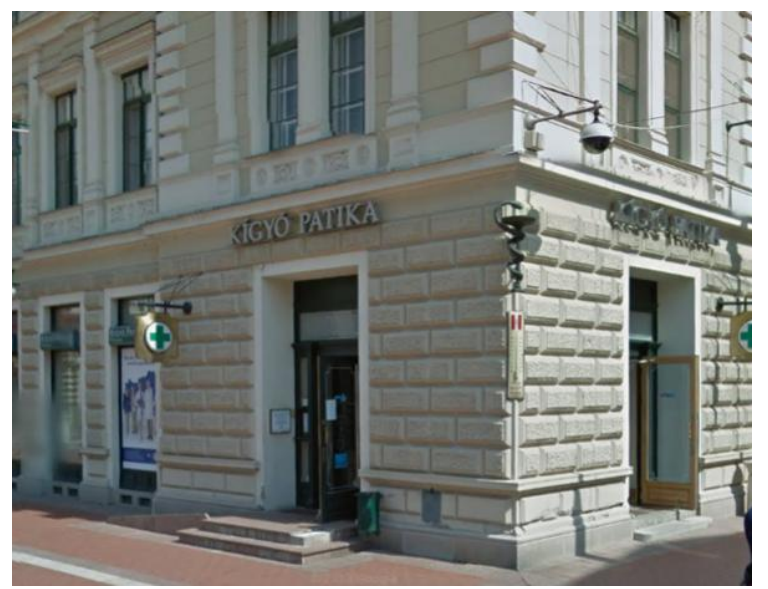

Fig. 7 Klauzal tér 3-where the "Kígyó" works.

After World War I, during the Soviet Republic, Hungary's Serbian, Romanian and French military occupying positions, the political and economic difficulties, we can say, the Gerle family survived without any trial. After the fall of the Soviet Republic, Charles Huszar became the country's prime minister for a short time, whodeclared the elections. On the 1st March, 1920, the National Assembly elected Miklós Horthy as a govenor [17]. The governor came to power and Szeged played a major role in it. From that time on the life of Jenö Gerle and the fate of his pharmacy were in the currents of history.

\subsection{Consequences of Jewish Laws and Regulations for the Fate of Pharmacy and Pharmacists}

The government of Darányi prepared and the office by president Bela Imrédy approved the Act XV of Law 1938 which is referred to be the first Jewish law. The law was passed on 29th May, 1938, and according to it in the position of white-collar professions there could be no more than $20 \%$ of Jewish origin. So this law maximized the number of employees from Jewish origin in $20 \%$ in commercial, financial and industrial companies employing more than 10 employees. Within five years this law had to be executed. The Jewish soldiers of the First World War (fire fighters) and of the counter-revolution receiving different merits and awards, the widows and children of the heroic dead, those who left the religion before August 1919 and their children, if they did not return to the Jewish religion were exempt from the law. With this, the seeds of racial definition appeared in the first antiJewish law. Fifty-nine non-Jewish artists and intellectuals protested against the law, but these actions were ineffective [18].

According to the Act IV of Law 1939 (limitation of use of public and economic space of the Jewish), 7720/1939th $\S 47$ which limited the presence of Jews in public and economic life, applied to issue an identity card of the employee. The personal page contained the worker's name, birth details and religion, as well as the date of his marriage and those of the parents, and both parents' parents' names, in other words the grandparents' names and their religion. On the form, there was a separate box left so that if any parent, grandparent changed his or her religion, the place, time and the name of the religion had to be registered there. Furthermore, the names of the 
children born in the marriage, their date of birth and date of christening had to be stated. There were two issues that had to be considered to be completed only by the Jewish people. One of them was the name, date and place of birth of the nearest Jewish ancestors born before 1 January 1849. The other was the exemptions specified in the Article 2 of Act IV of Law 1939 and on what basis and with what documents it could be certified. Moreover where and when the personal page was of issued and the signature of the person issuing [19].

Thanks to these regulations on 31 December 1940 Jenö Gerle had to dismiss two of his employees called Miklós Gergely and Paula Ausländer. Table 2 shows the registered staff of the pharmacy between 1902 and 1940.

There is neither any information about when Stephen Takáts, a pharmacist became the employee of the "Snake" pharmacy. The only fact which turned out was from the sales contract of the pharmacy. For example: his wife called Rózsika Bomsch, with whom he entered into a guarantee for payment. Their address was 15 Zerge street, Szeged.

Then Jenő Gerle was forcd to sell his pharmacy. The plan of the sales contract between Gerle and Takács in June 1940 remained, but the final contract have not been found yet. From later materials it is known that on 4th November, 1940, the final contract was signed and the jointly agreed price was 136,500 Pengö. A special permission was needed to transfer of the pharmacy from the Hungarian Royal Home Office. According to the contract, effective January 1, 1941, the real transfer of the pharmacy happened on 1st January, 1941 which meant the seller (Jeno Gerle) business running license was cancelled for the buyer (Takáts Stephen).

From this money Jenö Gerle bought a tenement $1 / 2$ stake holding with Lászó Desi, a resident of Budapest at 10 Bank Ban Street (earlier Parad street 11). The block of flats began to built in the autumn of 1940 based on the plan by József Kelemen architect. The number of approved building permission was 303314/1940. The truth is that the Jeno Gerle purchased the plot of land and on this land the three-story apartment building was built (Fig. 8). However the Gerles never moved to Budapest. Béla Ligeti, a cetrificated architect sas the caretaker of the house was asked to do the administration.Unfortunately the property in Budapest could not make profits because of the war events. Moreover they had to spend more money on it. After the siege of Budapest, though there were no fights any longer but population suffered from hunger, they were busy with clearing away the rubble and because of the unburied dead bodies epedemics were to start [20]. Damaged houses had to be repaired and redecoreted by the owners according to the law but there were not enough money and suitable materials to fulfil it. It is proved by a letter dated back 1949, five years after the war.

In the previous part it turned out that Jenö Gerle managed to survived the war in Hungary.

Table 2 The list of the names of employees between 1902 and 1940 (including their religion).

\begin{tabular}{|c|c|c|c|c|c|c|}
\hline Name & $\begin{array}{l}\text { Date/Place of } \\
\text { birth }\end{array}$ & Religion & Position & Date/Place of graduation & First day at work & Last day at work \\
\hline Gerle Jenő & $\begin{array}{l}\text { Ónod, } \\
1876.05 .24 .\end{array}$ & Jewish & $\begin{array}{l}\text { chief pharmacist, } \\
\text { owner }\end{array}$ & $\begin{array}{l}\text { Budapesten 1899; approbációs } \\
\text { vizsga: 1901.08.12. Budapest }\end{array}$ & 1902. 01.01. & 1941.01.01. \\
\hline Ausländer Paula & ?, 1880.09.10. & Jewish & cashier & - & 1903.02.01. & 1940.12 .31 \\
\hline Gergely Miklós & $\begin{array}{l}\text { Kányaháza, } \\
1889.01 .11 .\end{array}$ & Jewish & pharmacist & Budapest, 1914 & 1935.12.01. & 1940.12.31. \\
\hline Bein Nándor & $\begin{array}{l}\text { Sárospatak, } \\
1906 .\end{array}$ & Jewish & pharmacist & Szeged, 1931 & 1935.10.20. & \\
\hline $\begin{array}{l}\text { Szitner Jánosné } \\
\text { (Szabó Elza) }\end{array}$ & $\begin{array}{l}?, \\
1896.09 .06 .\end{array}$ & $\begin{array}{l}\text { Roman } \\
\text { Catholic }\end{array}$ & $\begin{array}{l}\text { temporary help, } \\
\text { pharmacist }\end{array}$ & Budapest, 1918 & 1938.09.01. & \\
\hline $\begin{array}{l}\text { Gerle Theodóra, } \\
\text { Ágnes } \\
\text { Takáts István * }\end{array}$ & $\begin{array}{l}\text { Szeged, } \\
1916.11 .28 .\end{array}$ & Jewish & $\begin{array}{l}\text { pharmacist trainee } \\
\text { pharmacist }\end{array}$ & - & 1937.09.01. & 1939.10.01. \\
\hline
\end{tabular}




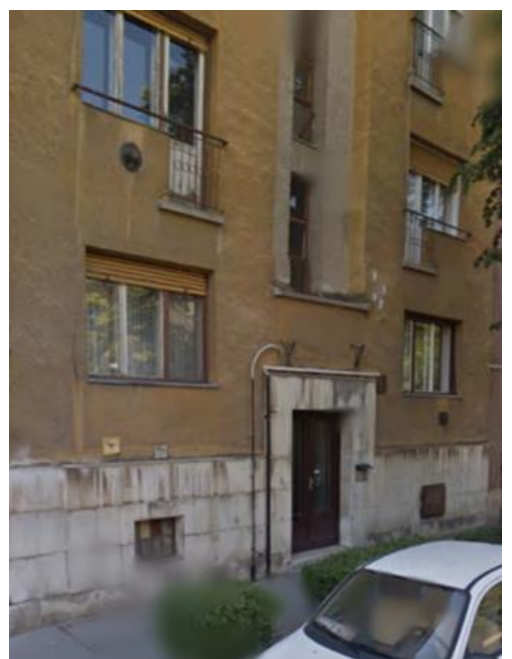

Fig. 8 The house of the Gerle family at 15 Bank Ban, Budapest.

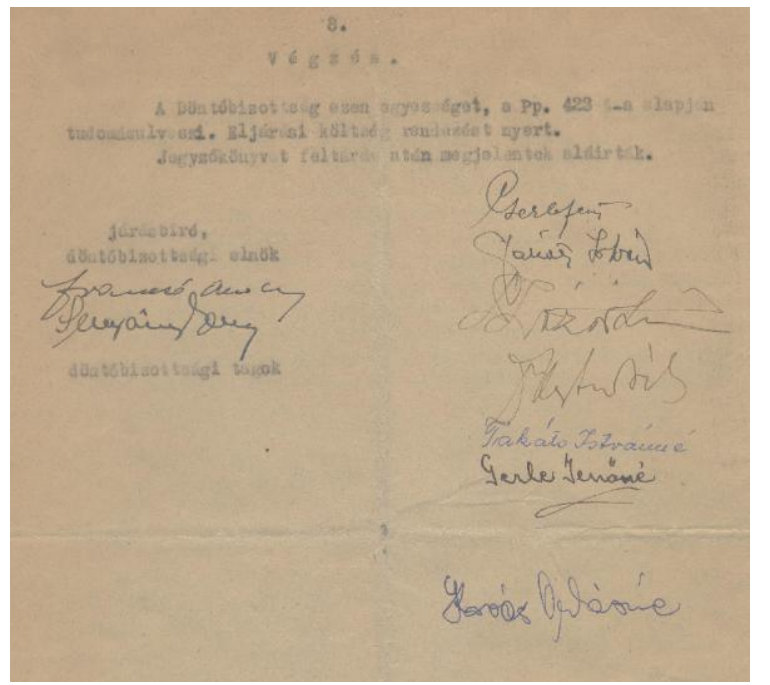

Fig. 9 The signatures of the last page.

Under the above mentioned Article 10480 of Law 1945 Jeno Gerle commissioned Dr. Béla Garden lawyer in Szeged to reclaim the pharmacy from pharmacist István Takáts. In order to support his legitimate demand, Jeno Gerle appealed to the Ministry, which was responded in writing by Dr. János Vikol Secretary of State on 16th November, 1945. In November 1945, in three pharmacies in Szeged, including the "Snake" pharmacy also an official guide was appointed. (In the three nominated pharmacies the pharmacy leaders: "Hungarians Védasszonya"-Dr. Bela Cross, "St. George"-László Kiss, "Snake"-Etelka Diener and then József Dr. Frankl).
According to the statement of $37,867 / 1945$ IX of Szeged City Mayor, pharmacies official managers were resinged - which was dated 28th December, 1945 - the "Hungarians Védasszonya" pharmacy's official manager called Just Frigyes, the "St. George" pharmacy's official operator called Frankl József, the "Snake" pharmacy's manager Jenő Gerle was appointed officially. The exchanges of each pharmacy official had to take place within three days. The protocol of the completed exchange of the "Snake" pharmacy management exists, on which the signatures are valuable (Fig. 9).

The case about the ownership of the pharmacy was still far from the end. Court case emerged in which the work of the District Court of Arbitration Committee Chairman, Dr. Count Kornel as a district judge, and Andor F. and József F. as members, lawyers representing the involved people in the case - also helped. Finally, as a result of the Arbitration Committee's meeting an agreement was reached. According to the agreement, the validity of the transfer was over, so the original licensee pharmacist, Jeno Gerle had to pay back the purchase money to the interim licensee pharmacist. The coverage or reimbursement was the property of the Gerle family in Bank Ban u.15 in Budapest. According to the agreement they became $50-50 \%$ of business partners, which concluded for five years, but Jenő Gerle had the ownership of the pharmacy and after his death his heirs inherited it (Fig. 9).

\subsection{Rakosi era and the Nationalization}

In the autumn of 1947 nationalization started. First the bigger banks, then in the spring of 1948 the medium sized factories and finally at the end of 1949 the private businesses employing more than 10 people were taken into public ownership.

Wealthy peasants were collected on the kulaks'list, and most of them were taken to "malenkij robot" (smal labour work) to the Soviet Union and privately owned field were forced to be united in big co-operative farms. 
Table 3 The pharmacies of Szeged between 1945-48, based on data in the yearbook of Pharmacists.

\begin{tabular}{|c|c|c|c|c|}
\hline Settlement & $\begin{array}{l}\text { Year of } \\
\text { foundation }\end{array}$ & Name of pharmacy & Name of owner & Renter (b), Taker(k), Leader(fv) \\
\hline Szeged & 1713 & Megváltó & Temesváry József & $\begin{array}{l}\text { Jeszenszkyné Kocsis Katalin } \\
(\mathrm{b}, \mathrm{fv})\end{array}$ \\
\hline Szeged & 1812 & Isteni gondviselés & Barcsay Károly & - \\
\hline Szeged & 1834 & Szentháromság & $\begin{array}{l}\text { dr. Leinzinger Móric, dr. Lehel } \\
\text { László, Muray Jné }\end{array}$ & Leinzinger Pál (t,fv) \\
\hline Szeged & $* 1850$ & Segítő Boldogasszony & dr. Löbl örökösök & Lázár Jenő (b) \\
\hline Szeged & $* * 1888$ & Kálvária & Pósa Balázs & - \\
\hline Szeged & $* * 1863$ & Szent Rókus & Surjányi József & - \\
\hline Szeged & 1869 & Szent György & Frankl József & - \\
\hline Szeged & 1870 & Szent István & dr. Salgó Éva & Tichy Béla (b,fv) \\
\hline Szeged & 1874 & Kígyó & $\begin{array}{l}\text { Gerle Jenő, üzlettárs } \\
\text { Takáts István }\end{array}$ & - \\
\hline Szeged & 1905 & Dugonics & Frankó Andor & - \\
\hline Szeged & 1907 & Erzsébet Királyné & Török Márton & - \\
\hline Szeged & 1908 & Magyar korona & Zakar Sándor örökösei & Máthé Mihály (fv) \\
\hline Szeged & 1913 & Remény & özv. Borbély Józsefné & Ugry István (b,fv) \\
\hline Szeged & 1914 & Csillag & özv. Nagy Györgyné & dr. Hangay Levente (fv) \\
\hline Szeged & 1923 & Magyarország Védasszonya & Just Frigyes & - \\
\hline Szeged & 1923 & Szent László & Apró Jenő & dr. Apró László (fv) \\
\hline Szeged & 1923 & Szent Szív & özv. Nyilassy Ágostonné & Bokor Mihályné (fv) \\
\hline Szeged & 1932 & Szent Ferenc & dr. Kotsis Endréné & - \\
\hline Szeged & 1932 & Szent Kereszt & Bulcsu Barna & - \\
\hline $\begin{array}{l}\text { Szeged } \\
\text { Alsóközpont }\end{array}$ & 1909 & Páduai Szt. Antal & $\begin{array}{l}\text { Mészáros Imréné (Apró } \\
\text { Borbála) }\end{array}$ & Mészáros Imre (fv) \\
\hline $\begin{array}{l}\text { Szeged } \\
\text { Felsőközpot }\end{array}$ & 1926 & Madonna & Marostői István & - \\
\hline Szeged Röszke & 1923 & Páduai Szt. Antal & $\begin{array}{l}\text { özv. Zakar Zoltánné (Kuthy } \\
\text { Gizella) }\end{array}$ & - \\
\hline $\begin{array}{l}\text { Szeged } \\
\text { Somogyi-telep }\end{array}$ & 1926 & Turul & Selmeczi Béla & - \\
\hline Szeged Újszeged & 1910 & Örangyal & Leskó Vilmos & - \\
\hline Szeged Várostanya & 1934 & Jézus Szíve & dr. Székács István & - \\
\hline
\end{tabular}

*Its original name was Segítő Mária;** In former documents the year of foundation was 1865; ***In former documents the year of foundation was 1865 .

According to Art XXV of Law 1950 all of the HUngarian pharmacies were taken into public ownership at the same time, namely on 28th July 1950. Stock taking and seizing was led by a three-membered committee. Nobody could stay in his own pharmacy. Some of them failed to become chief pharmacist later. It was not enough to be well-qualified, as they were concidered to be unreliable. Moreover two weeks before the pharmacy was taken into public ownership the owners had been ordered to fill up their stock. These bills had to be paid by the former owners after leaving the pharmacies (Table 3 ).

\section{Conclusion}

In summary, in the study of the Gerle family, the discovered data drew a picture of the hard, rough life of two people-Jenő Gerle, pharmacist and his daughter, Theodora - from the 20th century. According to the created image of the pharmacist, he was an economically well off, leaning Hungarian intellectual coming from a Jewish family. And as he grew up in this spirit he intended to provide the same for his own children. He chose his wife from a family thinking in a similar way and leading the similar lifestyle. His 
emotional bonds towards the Hungarians reflected in changing his name during his university years consciously and later, in the education of his daughters. His religious affiliation was not denied till his death. His Hungarian consciousness and Jewish origin, did not cause duality, he did not assimilate and was not two-faced. He rests in eternal peace in the Jewish cemetery, in the soil of his community.

Analyzing different documents helped up state that the examined person became the owner of a pharmacy in Szeged after he had graduated and had done his pharmaceutical practice in Budapest. Then he ran his own pharmacy where mainly Jewish employees were employed. However, due to the anti-Jewish laws first he had to dismiss some of his employees, later he was forced to sell his pharmacy. Surviving the war, according to the new laws he had the opportunity to claim his property again at court. Relying on the judgement it was revealed that the original pharmacist and the permanent licensed one became partners at a 50 and 50 per cent. But some time later according to Act XXV of Law 1950 all of the pharmacies in Hungary were brought under government management. Then the same happened to his every family-owned property and they could keep only the house where they lived. Jenö Gerle died at the age of 82 in Szeged. Both his daughters managed to survive the World War II but became widows, could enjoy the hospitality of the Hungarian Socialist Peoples'Rebublic and died childless.

\section{Acknowledgement}

Hereby acknowledgments are due to Vera Abraham working in the Jewish Archives of Szeged.

\section{References}

[1] Stevenson, D. 2004. 1914-1918: The History of the First World War. London: Allen Lane.

[2] The New Encyclopaedia Britanica, 15th ed., 2007. World War I. 286-9

[3] COMBAT- Theoretical Journal of The Communist League, The Hungarian "Soviet Republic" of 1919, Originally Published JUNE 1978: Accessed November 13.
2014

http://www.oneparty.co.uk/compass/combat/cb980601.ht $\mathrm{ml}$

[4] Gratz, G. 1935. Age of Revolutions. History of Hungary from 1918-1920. Budapest. (in Hungarian)

[5] Kun, B. 1935. International Socialist Library: Revolutionary Essays, B.S.P., 2IA Maiden Lane, Strand, London, W.C., Digitalized by Microsft 2014. (in Hungarian)

[6] The Encyclopedia Britannica, Miklós Horthy, Encyclopædia Britannica, Inc. Corporate Site. Accessed $18 \quad$ Aug, 2014. http://www.britannica.com/EBchecked/topic/272477/Mik los-Horthy.

[7] Johnson, N. P. A. S., and Mueller, J. D. 2002. Updating the Accounts: Global Mortality of the 1918-1920 „Spanish“ Influenza Pandemic, Bulletin of the History of Medicine, 76, 105-115

[8] Bibó,I. 1986. The Misery of Small States in Eastern Europe, Magvető, Budapest, 234-8. (in Hungarian)

[9] Bekény, I. and Dányi, D., 1996-2000, Hungary XX. Century. Babits Publisher, Szekszárd, Volume 4. 683-9. (in Hungarian)

[10] Holocaust Encyclopedia: German Occupation of Hungary, $\begin{array}{llll}\text { Accessed } & 13 & \text { Jan, } & 2015\end{array}$ http://www.ushmm.org/wlc/en/article.php?ModuleId=100 05457Holocaust.

[11] Borhi, L. 2004. Hungary in the Cold War, 1945-1956. London. Central European University Press. 138-42.

[12] Swain, N. 1992. The Rise and Fall of Feasible Socialism. New Left Books, London, 673-9.

[13] Botos, J. 1995. 100 years of the state registration of births (1895-1995), Magvető, Budapest, 854-62. (in Hungarian)

[14] Bakos, F. 1957. Foreign Words and Phrases in Dictionary, Budapest, Akadémia, 653. (in Hungarian)

[15] Fritsch, T. 1933. Handbbok of the Question of Jewish. Deutschland, Leipzig, 965-7.

[16] Kollega-Tarsoly, I. 1996-2000. Hungary XX. Century, Szekszárd. Babits Publisher, 4: 25-32. (in Hungarian)

[17] Original Jewish Documents. 1960. Jenő Gerle, curriculum vitae. Szeged. Archives of Jewish Library. Hungary.

[18] Hungarian Gazette, 15 March 1945. Accessed 13 Dec. 2014. (in Hungarian)

[19] http://dtt.ogyk.hu/hu/gyujtemenyismertetok/jogforrasok/h ivatalos-kozlonyok/item/417-magyar-kozlony-1945-napja inkig.

[20] The Encyclopedia Britannica, Miklós Horthy, Encyclopædia Britannica, Inc. Corporate Site. Accessed $21 \quad$ Jan. 2015. http://www.britannica.com/EBchecked/topic/272477/Mik los-Horthy..

[21] Tilkovszky, L. 1997. Jewish Laws as the Antecedant of 
Holocaust and the Holocaust in Hungary. Fifty Years Later, edited by Randolph, L., and Pók, A. New York: Columbia University Press, 117-35.

[22] Jewish Laws. Accessed 18 Nov. 2014.
http://www.jewishvirtuallibrary.org/jsource/vjw/Hungary. html

[23] Balázs, M., 2014. Guide 1944-1945 Siege of Budapest, Budapest. Underground Press. 238-245. 